\title{
PERCEIVED SOURCE OF STRESS AMONG DENTAL COLLEGE STUDENTS IN KANCHEEPURAM DISTRICT
}

\section{Mahalakshmi .M*., Gokkulakrishnan Sadhasivam., Karthikeyan Maruthamuthu., Suresh Kumar.G., Abishek R.Balaji and SrinivasaluPabbaraju}

\author{
Department of OMFS, Adhiparasakthi Dental College \& Hospital, Melmaruvathur. \\ The Tamilnadu Dr MGR Medical University \\ DOI: http://dx.doi.org/10.24327/ijrsr.2017.0803.0038
}

\section{ARTICLE INFO}

\section{Article History:}

Received $15^{\text {th }}$ December, 2016 Received in revised form $25^{\text {th }}$ January, 2017

Accepted $28^{\text {th }}$ February, 2017

Published online $28^{\text {th }}$ March, 2017

\section{Key Words:}

Dental Undergraduate

Students, Kancheepuram,

Stress

\begin{abstract}
Aim: To identify the sources and levels of stress is imperative in dental education programme. By reducing such stress, we can bring healthy environment in dental school. The purpose of the study was to address the potential source of stress among dental college students and its relation with gender and year of study.

Materials and Methods: A modified Dental environment stress (DES) questionnaire comprised of 24 questions was used to assess the level of stress. The response to the questionnaire was based on a four-point likert type of scale, not stressful to severely stressful. Statistical analysis was done using SPSS package version 22.0.significant level fixed as 5\%.

Results: A total of 600 Undergraduate students constituted the study population. Of the participants $45 \%$ (270) were men and 55\% (330) were women. Majority of students felt stressed about full working day. Second year students had greater stress among all four academic years.

Conclusion: The principal source of stress were full working day. There was significant difference in stress perception between genders and year of study. It implies that there is a need for student counselors and faculty advisors along with academic programme.
\end{abstract}

Copyright (C) Mahalakshmi.M et al, 2017, this is an open-access article distributed under the terms of the Creative Commons Attribution License, which permits unrestricted use, distribution and reproduction in any medium, provided the original work is properly cited.

\section{INTRODUCTION}

Stress is defined as perception of discrepancy between environment demands and individual capacities to fulfill those demands. Stress develops due to excessive pressure or different type of demands placed on them ${ }^{1}$

A literature review on potential stressors and coping techniques in dentistry suggests that this stress starts from dental school itself. $^{2}$

Stress is a significant threat that can result in physical or mental illness, and may have a strong negative effect on student's academics and their consecutive practice in dentistry. ${ }^{3}$ stress can lead to anxiety, depression, decreased work efficiency and burn out in dental students ${ }^{4}$. Dentists suffer from especially high degrees of stress even when compared with other health professions $^{5-6}$

In the literature so many stress related studies for dental students available. Perceived source of stress among under graduate dental students at the University of Jordan were examined in the year 2000 .
In India especially in Tamilnadu has strong family and culture values from ancient time itself. Respect for parents \& elders and heeding their advice is sacred. Parents who cannot fulfill their dreams of professional education try to fulfill it through their children. In many cases, the children are forced by their parents to pursue a career that is not of their choice.

As per dental council of India (DCI) regulations, the Bachelor of Dental Surgery, is four years program with progression examination at the end of each year followed by one year Rotatory internship in the dental college and is governed by the DCI. During the first two years of graduation, students are taught basic sciences and preclinical dentistry whereas the later years are dedicated for clinical education ${ }^{7}$.

Though the fees structure for dentistry is the highest next to medicine, job opportunities in government and private sector are little.

The aim of this study was to determine the perceived source of stress among the dental undergraduate students at six private dental institution in kancheepuram district affliated to Tamilnadu Dr MGR Medical University, Chennai. 


\section{MATERIALS AND METHODS}

\section{Procedure}

Verbal consent was obtained from the respondents and ethical approval for performing the survey was availed from the ethical committee of Adhiparasakthi Dental College and Hospital.

Stress was measured using a modified dental environment stress questionnaire which consisted of 24 questions that are applicable only to indian dental education background.

Questions related to clinical training 20, 21,22,23,24 were excluded from the questionnaire administered to non clinical students (first and second year). The response of each question was based on a Likert-type scale with response of 1-not stressful, 2- slightly stressful,3-moderately stressful,4-severly stressful. The study was conducted in six private dental institution in kancheepuram district. Each college hundred students were participated in the study. Each year 25 volunteer students were asked to participate in the study. Internees were excluded from the study. Questionnaire were distributed by the authors during one lecture for each year with prior permission from the dean of the each institution and aims of the study were explained. Along with the questionnaire they were asked to record data regarding age, gender and year of study.

\section{Statistical analysis}

The statistical package for social sciences (SPSS) version 22.0 software was used for data processing and data analysis. Mean values and standard deviations were calculated for each stressor.

Analysis of variance (ANOVA) was used to compare scores between year of study. Independent $\mathrm{T}$ sample t-test was applied to compare scores between genders, preclinical and clinical students, gender among preclinical, gender among clinical students. For multiple pair wise comparision Tukey's HSD post hoc tests was used. Significance level is $5 \%(0.05)$

\section{Study population}

A total of 600 students from six private dental institution in kancheepuram district were participated in the study. The response of each college was $16.7 \%$

\section{RESULTS}

\section{Demographic Profile}

Total number of students participated in the study were 600 , out of them $270(45 \%)$ were males $330(55 \%)$ were females. The number of first year students were 150 (25\%), second year $149(24.8 \%)$, third year $151(25.2 \%)$, fourth year $151(25.2 \%)$ (Table 1)

Table 1 Demographic Profile

\begin{tabular}{ccccccc}
\hline \multirow{3}{*}{ Year of study } & \multicolumn{6}{c}{ Gender } \\
\cline { 2 - 7 } & \multicolumn{2}{c}{ Male } & \multicolumn{2}{c}{ Female } & \multicolumn{2}{c}{ Total } \\
\cline { 2 - 7 } & $\mathrm{N}$ & $\%$ & $\mathrm{~N}$ & $\%$ & $\mathrm{~N}$ & $\%$ \\
\hline First & 70 & 46.7 & 80 & 53.3 & 150 & 100.0 \\
Second & 74 & 49.7 & 75 & 50.3 & 149 & 100.0 \\
Third & 61 & 40.7 & 89 & 59.3 & 150 & 100.0 \\
Fourth & 65 & 43.0 & 86 & 57.0 & 151 & 100.0 \\
Total & 270 & 45.0 & 330 & 55.0 & 600 & 100.0 \\
\hline
\end{tabular}

\section{Percived Stressors for Dental Graduate Students}

Stress scores for each question in every year are summarized in table 2. ANOVA was applied to compare mean value between years of studies.

The highest mean score was 3.75 full working day was greatest stressors followed by lack of time for relaxation and lack of time to do assigned college work.

Out of 24 questionaire 11 had significant differences across year groups.

In the study, it was found that lack of time to do assigned college work was the greatest stress in the final year and second year students. For the third year and first year students felt that the dominating stress was the full working day.

\section{Stress Factor by Gender}

Stress score by gender in whole are measured by applying independent sample-T test(Table 3) The greatest stressor for male is fear of failing a course (mean=3.93) followed by full working day \& lack of time to do assign college work

Whereas in female full working day was the greatest stress followed by lack of time for relaxation \& lack of time to do assign college work

\section{Stress Factor between Preclinical \& Clinical Students}

Stress factor was compared between pre clinical (I\&II year) and clinical students (III\&IV year) by using independent sample $\mathrm{T}$ test (Table4). Among preclinical students (I\&IIyear) lack of time to do assign college work was the greatest stressor followed by full working day and lack of time for relaxation .In clinical students (III\&IV year) Lack of time for relaxation was the major stressor. The second most stressor was full working day followed by lack of time to do assign college work.

Among preclinical male students, the greatest stressor was lack of time to do assigned college work followed by full working day $\&$ fear of failing a course or the year (Table5)

In female preclinical students, full working day was the greatest stressor. Lack of time to do assigned college work followed by lack of time for relaxation were the other stressors. Male, female stress factor in clinical students $\left(3^{\text {rd }}\right.$ and $4^{\text {th }}$ year) were compared by using independent sample test (Table 6)

In male students, fear of failing a course or the year was the major stress factor followed by lack of time for relaxation and full working day.

In female students, lack of time for relaxation was the greatest stress or followed by full working day and lack of time to do assigned college work.

\section{DISSCUSSION}

The highest mean scores were observed in all the four years respectively (I-3.79, II-3.84, III-3.77, IV-3.81) with peak in $2^{\text {nd }}$ year which favour the result of newton et $^{\mathrm{a}} \mathrm{l}^{8}$.

Stress level compared between preclinical and clinical students. Among the preclinical students $2^{\text {nd }}$ year had more stress than ${ }^{1 \text { st }}$ year. Among the clinical students 4 th year had more stress than $3^{\text {rd }}$ year. 
Table 2 Perceived Stressors for Dental Graduate Students

\begin{tabular}{|c|c|c|c|c|c|c|c|}
\hline & Stress item & I year & II year & III year & IV year & $P$ value & Significance \\
\hline 1 & Fear of failing a course or the year & $3.55+.630$ & $344+.720$ & $3.31+.794$ & $3.38+.823$ & 0.033 & Significant \\
\hline 2 & $\begin{array}{c}\text { Lack of confidence to be successful dental } \\
\text { Student }\end{array}$ & $2.26+.893$ & $2.43+.988$ & $2.57+.915$ & $2.42+.882$ & 0.034 & Significant \\
\hline 3 & $\begin{array}{l}\text { Fear of not being able to join a post graduation dental education } \\
\text { programmes }\end{array}$ & $3.31+.761$ & $3.33+.817$ & $3.21+.816$ & $3.27+.879$ & 0.619 & Not significant \\
\hline 4 & Fear of being unable to catch up it getting behind the work & $3.21+.780$ & $3.28+.806$ & $3.17+.817$ & $2.95+.904$ & 0.005 & Significant \\
\hline 5 & Insecurity concerning professional failure & $2.26+.893$ & $2.43+.988$ & $2.57+.915$ & $2.42+.882$ & 0.034 & Significant \\
\hline 6 & Insecurity concerning lack of employment position & $2.14+.786$ & $2.17+.833$ & $2.35+.859$ & $2.21+.811$ & 0.115 & Not significant \\
\hline 7 & Lack of confidence in own decision making & $2.26+.893$ & $2.43+.988$ & $2.57+.915$ & $2.42+.882$ & 0.034 & Significant \\
\hline 8 & Language barrier & $2.14+.786$ & $2.17+.833$ & $2.35+.859$ & $2.19+.752$ & 0.115 & Significant \\
\hline 9 & Lack of confidence to be a successful dentist & $1.92+.690$ & $2.28+.715$ & $2.13+.762$ & $2.16+.795$ & 0.001 & Not significant \\
\hline 10 & Inconsistency of feedback on work between different instructors & $2.26+.893$ & $2.43+.988$ & $2.57+.915$ & $2.42+.882$ & 0.034 & Significant \\
\hline 11 & Receiving criticism about work & $2.14+.786$ & $2.17+.833$ & $2.35+.859$ & $2.19+.752$ & 0.115 & Significant \\
\hline 12 & Getting study material & $2.26+.893$ & $2.43+.988$ & $2.57+.915$ & $2.42+.882$ & 0.034 & Not significant \\
\hline 13 & Shortage of allotted clinical time & $2.14+.786$ & $2.17+.833$ & $2.35+.859$ & $2.19+.752$ & 0.115 & Not significant \\
\hline 14 & Amount of cheating in dental faculty & $2.26+.893$ & $2.43+.988$ & $2.57+.915$ & $2.42+.882$ & 0.034 & Not significant \\
\hline 15 & Approachability of teaching staff & $2.14+.786$ & $2.117+.833$ & $2.35+.859$ & $2.19+.752$ & 0.115 & Significant \\
\hline 16 & Amount of assigned class work & $2.26+.893$ & $2.43+.988$ & $2.57+.915$ & $2.42+.925$ & 0.034 & Significant \\
\hline 17 & Lack of time to do assigned college work & $3.74+.650$ & $3.84+.521$ & $3.53+.841$ & $3.81+.562$ & $<0.001$ & Significant \\
\hline 18 & Lack of time for relaxation & $3.71+.698$ & $3.65+.657$ & $3.76+.598$ & $3.80+.432$ & 0.164 & Not significant \\
\hline 19 & Full working day & $3.79+.406$ & $3.76+.430$ & $3.77+.424$ & $3.68+.470$ & 0.102 & Not significant \\
\hline 20 & Lack of cooperation by patients in their home care & 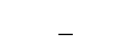 & 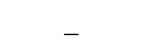 & $2.19+.865$ & $2.46+.862$ & 0.009 & Significant \\
\hline 21 & $\begin{array}{l}\text { Fear of dealing with patients who donotdisclose the existence of a } \\
\text { contagious diseases }\end{array}$ & - & - & $2.30+.833$ & $2.46+.907$ & 0.119 & Not significant \\
\hline 22 & Working on patients with dirty mouth & & & $2.35+.938$ & $2.43+.891$ & 0.271 & Not significant \\
\hline 23 & Difficulty in learning clinical procedures & - & - & $2.47+.924$ & $2.44+.892$ & 0.827 & Not significant \\
\hline 24 & Difficulty in learning precision manual skills & & & $2.53+.895$ & $2.42+.867$ & 0.282 & Not significant \\
\hline
\end{tabular}

Table 3 Stress Factor by Gender

\begin{tabular}{|c|c|c|c|c|c|}
\hline S.NO & Stress item & Male & Female & P value & Significance \\
\hline 1 & Fear of faliing a course or the year & $3.79+.482$ & $3.11+.789$ & $<0.001$ & Significant \\
\hline 2 & Lack of confidence to be successful dental Student & $2.31+.924$ & $2.51+.917$ & 0.009 & Significant \\
\hline 3 & $\begin{array}{c}\text { Fear of not being able to join a post graduation } \\
\text { Dental education programmes }\end{array}$ & $3.58+.761$ & $3.04+.783$ & $<0.001$ & Significant \\
\hline 4 & Fear of being unable to catch up it getting behind the work & $3.39+.837$ & $2.96+.782$ & $<0.001$ & Significant \\
\hline 5 & Insecurity concerning professional failure & $2.31+.924$ & $2.51+.917$ & 0.009 & Significant \\
\hline 6 & Insecurity concerning lack of employment position & $2.12+.795$ & $2.28+.816$ & 0.012 & Significant \\
\hline 7 & Lack of confidence in own decision making & $2.31+.924$ & $2.51+.917$ & 0.009 & Significant \\
\hline 8 & Language barrier & $2.12+.795$ & $2.28+.816$ & 0.012 & Significant \\
\hline 9 & Lack of confidence to be a successful dentist & $2.14+.750$ & $2.10+.752$ & 0.475 & Not significant \\
\hline 10 & Inconsistency of feedback on work between different instructors & $2.31+.924$ & $2.51+.917$ & 0.009 & Significant \\
\hline 11 & Receiving criticism about work & $2.12+.795$ & $2.28+.816$ & 0.012 & Significant \\
\hline 12 & Getting study material & $2.31+.924$ & $2.51+.917$ & 0.009 & Significant \\
\hline 13 & Shortage of allotted clinical time & $2.12+.795$ & $2.28+.816$ & 0.012 & Significant \\
\hline 14 & Amount of cheating in dental faculty & $2.31+.924$ & $2.51+.917$ & 0.009 & Significant \\
\hline 15 & Approachability of teaching staff & $2.12+.765$ & $2.28+.816$ & 0.012 & Significant \\
\hline 16 & Amount of assigned class work & $2.31+.924$ & $2.51+.917$ & 0.009 & Significant \\
\hline 17 & Lack of time to do assigned college work & $3.76+.614$ & $3.71+.703$ & 0.323 & Not significant \\
\hline 18 & Lack of time for relaxation & $3.74+.536$ & $3.72+.658$ & 0.641 & Not significant \\
\hline 19 & Full working day & $3.77+.424$ & $3.73+.443$ & 0.350 & Not significant \\
\hline 20 & Lack of cooperation by patients in their home care & $2.34+.841$ & $2.31+.896$ & 0.792 & Not significant \\
\hline 21 & $\begin{array}{c}\text { Fear of dealing with patients who do not disclose the existence of a contagious } \\
\text { diseases }\end{array}$ & $2.35+.842$ & $2.40+.897$ & 0.619 & Not significant \\
\hline 22 & Working on patients with dirty mouth & $2.45+.917$ & $2.51+.915$ & 0.563 & Not significant \\
\hline 23 & Difficulty in learning clinical procedures & $2.44+.844$ & $2.46+.951$ & 0.862 & Not significant \\
\hline 24 & Difficulty in learning precision manual skills & $2.37+.891$ & $2.55+.869$ & 0.075 & Not significant \\
\hline
\end{tabular}

Table 4 Stress Factor between Preclinical \& Clinical Students

\begin{tabular}{|c|c|c|c|c|c|}
\hline S.NO & Stress item & Pre clinical & Clinical & P value & Significance \\
\hline 1 & Fear of faliing a course or the year & $3.49+.677$ & $3.34+.808$ & 0.012 & Significant \\
\hline 2 & $\begin{array}{c}\text { Lack of confidence to be successful dental } \\
\text { Student }\end{array}$ & $2.34+.944$ & $2.50+.900$ & 0.046 & Significant \\
\hline 3 & $\begin{array}{c}\text { Fear of not being able to join a post graduation } \\
\text { Dental education programmes }\end{array}$ & $3.32+.788$ & $3.24+.847$ & 0.240 & Not significant \\
\hline 4 & Fear of being unable to catch up it getting behind the work & $3.24+.793$ & $3.06+868$ & 0.008 & Significant \\
\hline 5 & Insecurity concerning professional failure & $2.34+.944$ & $2.50+.900$ & 0.046 & Significant \\
\hline 6 & Insecurity concerning lack of employment position & $2.15+.809$ & $2.27+.810$ & 0.091 & Not significant \\
\hline 7 & Lack of confidence in own decision making & $2.34+.944$ & $2.50+.900$ & 0.046 & Significant \\
\hline 8 & Language barrier & $2.15+.809$ & $2.27+.810$ & 0.091 & Not significant \\
\hline 9 & Lack of confidence to be a successful dentist & $2.10+.724$ & $2.14+.778$ & 0.451 & Not significant \\
\hline 10 & Inconsistency of feedback on work between different instructors & $2.34+.944$ & $2.50+.900$ & 0.046 & Significant \\
\hline
\end{tabular}




\begin{tabular}{|c|c|c|c|c|c|}
\hline 11 & Receiving criticism about work & $2.15+.809$ & $2.27+.810$ & 0.091 & Not significant \\
\hline 12 & Getting study material & $2.34+.944$ & $2.50+.900$ & 0.046 & Significant \\
\hline 13 & Shortage of allotted clinical time & $2.15+.809$ & $2.27+.810$ & 0.091 & Not significant \\
\hline 14 & Amount of cheating in dental faculty & $2.34+.944$ & $2.50+.900$ & 0.046 & Significant \\
\hline 15 & Approachability of teaching staff & $2.15+.809$ & $2.27+.810$ & 0.091 & Not significant \\
\hline 16 & Amount of assigned class work & $2.34+.944$ & $2.50+.900$ & 0.046 & Not significant \\
\hline 17 & Lack of time to do assigned college work & $3.79+.590$ & $3.67+.727$ & 0.029 & Significant \\
\hline 18 & Lack of time for relaxation & $3.68+.678$ & $3.78+.521$ & 0.047 & Significant \\
\hline 19 & Full working day & $3.78+.418$ & $3.72+.449$ & 0.121 & Not significant \\
\hline 20 & Lack of cooperation by patients in their home care & - & $2.33+.872$ & - & Significant \\
\hline 21 & $\begin{array}{c}\text { Fear of dealing with patients who do not disclose the existence of a contagious } \\
\text { diseases }\end{array}$ & - & $2.38+.873$ & - & Significant \\
\hline 22 & Working on patients with dirty mouth & - & $2.49+.915$ & - & Significant \\
\hline 23 & Difficulty in learning clinical procedures & - & $2.46+.907$ & - & Significant \\
\hline 24 & Difficulty in learning precision manual skills & & $2.47+.881$ & & Significant \\
\hline
\end{tabular}

Table 5 Gender among preclinical students

\begin{tabular}{|c|c|c|c|c|c|}
\hline S.NO & Stress item & Male & Female & P value & Significance \\
\hline 1 & Fear of faliing a course or the year & $3.76+.502$ & $3.25+.724$ & $<0.001$ & Significant \\
\hline 2 & Lack of confidence to be successful dental Student & $2.28+.921$ & $2.40+964$ & 0.292 & Not significant \\
\hline 3 & $\begin{array}{c}\text { Fear of not being able to join a post graduation } \\
\text { Dental education programmes }\end{array}$ & $3.51+.811$ & $3.14+.723$ & $<0.001$ & Significant \\
\hline 4 & Fear of being unable to catch up it getting behind the work & $3.46+.810$ & $3.05+.724$ & $<0.001$ & Significant \\
\hline 5 & Insecurity concerning professional failure & $2.28+.921$ & $2.40+.964$ & 0.292 & Not significant \\
\hline 6 & Insecurity concerning lack of employment position & $2.10+.808$ & $2.20+.809$ & 0.307 & Not significant \\
\hline 7 & Lack of confidence in own decision making & $2.28+.921$ & $2.40+.964$ & 0.292 & Not significant \\
\hline 8 & Language barrier & $2.10+.808$ & $2.20+.809$ & 0.307 & Not significant \\
\hline 9 & Lack of confidence to be a successful dentist & $2.11+.649$ & $2.08+.789$ & 0.746 & Not significant \\
\hline 10 & Inconsistency of feedback on work between different instructors & $2.28+.921$ & $2.40+.962$ & 0.292 & Not significant \\
\hline 11 & Receiving criticism about work & $2.10+.808$ & $2.20+.809$ & 0.307 & Not significant \\
\hline 12 & Getting study material & $2.28+.921$ & $2.40+.964$ & 0.292 & Not significant \\
\hline 13 & Shortage of allotted clinical time & $2.10+.808$ & $2.20+.809$ & 0.307 & Not significant \\
\hline 14 & Amount of cheating in dental faculty & $2.28+.921$ & $2.40+.964$ & 0.292 & Not significant \\
\hline 15 & Approachability of teaching staff & $2.10+.808$ & $2.20+.809$ & 0.307 & Not significant \\
\hline 16 & Amount of assigned class work & $2.28+.921$ & $2.40+.964$ & 0.292 & Not significant \\
\hline 17 & Lack of time to do assigned college work & $3.81+.542$ & $3.71+.613$ & 0.513 & Not significant \\
\hline 18 & Lack of time for relaxation & $3.71+.613$ & $3.66+.734$ & 0.522 & Significant \\
\hline 19 & Full working day & $3.76+.426$ & $3.79+.411$ & 0.632 & Significant \\
\hline
\end{tabular}

Table 6 Gender among clinical students

\begin{tabular}{|c|c|c|c|c|c|}
\hline S.NO & Stress item & Male & Female & P value & Significance \\
\hline 1 & Fear of faliing a course or the year & $3.83+.457$ & $2.99+.827$ & $<0.001$ & Significant \\
\hline 2 & Lack of confidence to be successful dental Student & $2.34+.931$ & $2.61+.864$ & 0.012 & Significant \\
\hline 3 & $\begin{array}{c}\text { Fear of not being able to join a post graduation } \\
\text { Dental education programmes }\end{array}$ & $3.66+.695$ & $2.94+.822$ & $<0.001$ & Significant \\
\hline 4 & Fear of being unable to catch up it getting behind the work & $3.32+.864$ & $2.88+.825$ & $<0.001$ & Significant \\
\hline 5 & Insecurity concerning professional failure & $2.34+.931$ & $2.61+.864$ & 0.012 & Significant \\
\hline 6 & Insecurity concerning lack of employment position & $2.13+.783$ & $2.36+.818$ & 0.116 & Significant \\
\hline 7 & Lack of confidence in own decision making & $2.34+.931$ & $2.61+.864$ & 0.12 & Significant \\
\hline 9 & Lack of confidence to be a successful dentist & $2.18+.852$ & $2.11+.720$ & 0.458 & Significant \\
\hline 10 & Inconsistency of feedback on work between different instructors & $2.34+.931$ & $2.61+.864$ & 0.012 & Significant \\
\hline 11 & Receiving criticism about work & $2.13+.783$ & $2.36+.818$ & 0.016 & Significant \\
\hline 12 & Getting study material & $2.34+.931$ & $2.61+.864$ & 0.012 & Significant \\
\hline 13 & Shortage of allotted clinical time & $2.13+.783$ & $2.36+.818$ & 0.016 & Significant \\
\hline 14 & Amount of cheating in dental faculty & $2.34+.931$ & $2.61+.864$ & 0.012 & Significant \\
\hline 15 & Approachability of teaching staff & $2.13+.783$ & $2.36+.818$ & 0.016 & Significant \\
\hline 16 & Amount of assigned class work & $2.34+.931$ & $2.61+.864$ & 0.012 & Significant \\
\hline 18 & Lack of time for relaxation & $3.79+.431$ & $3.78+.579$ & 0.888 & Significant \\
\hline 19 & Full working day & $3.77+.423$ & $3.69+.466$ & 0.104 & Significant \\
\hline 20 & Lack of cooperation by patients in their home care & $2.34+.841$ & $2.31+.896$ & 0.792 & Significant \\
\hline 21 & $\begin{array}{l}\text { Fear of dealing with patients who do not disclose the existence of a } \\
\text { contagious diseases }\end{array}$ & $2.35+.842$ & $2.40+.897$ & 0.619 & Not significant \\
\hline 22 & Working on patients with dirty mouth & $2.45+.917$ & $2.51+915$ & 0.563 & Not significant \\
\hline 23 & Difficulty in learning clinical procedures & $2.44+.844$ & $2.46+.951$ & 0.862 & Not significant \\
\hline 24 & Difficulty in learning precision manual skills & $2.37+.891$ & $2.55+.869$ & 0.075 & Not significant \\
\hline
\end{tabular}

This is contrary to various studies where stress increases from preclinical to clinical training ${ }^{7}$ and in some studies where non clinical years were more stressful by westerman et $a l^{9}$. The major stressors was the full working day. The mean score was (3.75).
This is contrary to various previous studies ${ }^{10-1 /}$ in which examination and grades were the first major stressors conducted in USA, Singapore, Australia and Jordan. This may be due to that examination and grades were not included in the questionnaire study. The second most common stressors was 
the lack of time for relaxation. The students had a lot of work commitments during their studies like quota to fullfil their academic curriculum. Due to less availability of patients because of budding of so many dental colleges, they need to concentrate on getting patients in their college time. So their relaxation became less during the college studies.

Fear of not being able to join a post graduate dental education program was one of the top 5 stressors among pre clinical and clinical year students in both the gender. This is because of less number of merit post graduation seats available in all over India. To pursue a post graduate dental degree other than merit need to spend a lot of money in India. For the above reasons fear of not able to join a post graduation dental education program was the one of the stressor. To rectify this our Indian government should introduce a merit based nominal fees \&post graduation dental degree in all private institution so that low \& medium income parents of dental students can avail this opportunity. These dental students join the post graduation course very easily \& quickly.

But in another way, insecurity concerning the lack of employment position was statstically insignificant in all the four year student. The mean value was 2.21. This may be due to that students are not much serious on employment of dentist. This was contrast to another study in which insecurity regarding future career was high ${ }^{14}$. In indiapractically speaking the employment opportunity for dentist is less both in the government and private sector. Getting employment in India is still a problem for all job seeking dentist in India. The dental student may not aware of these situation was one of the reason for these results.

There was a strong relationship between gender and perceived source of stress. In this study both clinical \& preclinical years male showed the higher level of stress than females. The same result was obtained by Achary ${ }^{18}$ in his study on Indian dental students. This was contrary to other findings that did not support any gender difference ${ }^{19}$ or showed that females experienced greater stress $9,15,20$

In this study, the greatest stressor in males of clinical years was fear of failing a course or the year. This favoured the previous studies $^{21}$.

There are so many programs had been implemented to evaluate the stress in dental students $\&$ to reduce the stress by specific courses, stress reduction session, faculty incorporated advising system \& appointment of psychologist Tisdelle et $a l^{22}$ supported that such training scheme faster coping behavior that are useful on daily basis, as well as preventing measures to reduce chronic stress effect. Schwartz et ll $^{23}$, the establishment of student advisor and counsellors within a dental school, combined with a faculty advising system and student-oriented programmes, have contributed to an improved educational environment.

Faculty of Tokyo medical \& dental university (TMDU) ${ }^{24}$ planed to launch a view on curriculum including problem based learning \& early exposure systems, along with providing greater flexibility for students to develop professional attitude.

The reconsideration of the existing educational system towards a more students centured orientation could facilitate collaboration learning and interpersonal support amongst students, which may have a productive effect against difficulties faced whilst in dental institution.

A modified student based curriculum should bedesigned then only stress of the dental students can be decreased. A friendly environment should be created by the dental teaching staff to reduce the anxiety or fear of the dental students. More over periodic psychologist counseling should be included in the curriculum. Through this interaction of dental students with psychologist can motivate the students in academic performance and minimize stress.

If these modifications are introduced, hopefully dental students stress will be reduced and will get healthy environment training, all lead to be a successful dentists in future.

\section{CONCLUSION}

This study was done to assist the perceived source and factors affecting stress among students in the private dental schools in kancheepuram, Tamilnadu. Some of the conclusion.

- Prevalence of stress was high among dental students

- Male students suffered from greater stress compared to females

- Full working day was found to be the most stressful item among the students

- Second year students had greater stress due to transition from preclinical to clinical year.

- Fear of failing a course or the year was found to be most stressful in male student whereas full working day was the major stressor in female students.

\section{References}

1. Agolla JE, Ongori. H. An assessment of academic stress among undergraduate students :The case University of Botswana.Edu Res Rev 2009;4(2):63-70

2. Alaujan AH, Alzahem AM stress among dentists: Gen Dent.20;52(5):428-432

3. Alzahem AM, Van der Molen HT, Alaujan AH, Schmidt HG, Zamakhshary MH: stress amongst dental students: a systematic revieWw

4. POhlmann K, Jonas I, Ruf S, Harzer W. Stress, burnout and health in the clinical period of dental education. Eur $J$ Dent Edu.2005; 9:78-84.

5. Baldwin PJ, Dodd M, Rennie JS. Young dentists - work, wealth, health and happiness. $B r$ Dent $J$ 1999: 186: 30-36.

6. Gorter RC, Eijkman MA, Hoogstraten J. Burnout and health among Dutch dentists. Eur J Oral Sci 2000: 108: 261-26

7. Kumar S, Dagli RJ, Mathur A, Jain M, Prabu D, Kulkarni S Perceived sources of stress amongst Indian dental students. Eur J Dent Educ 2009; 13:39-45.

8. Newton JT, Baghaienaini F, Goodwin SR, Invest J, Lubbock, Saghakhaneh NM. Stress in dental schools: a survey of students. Dent Update 1994: 21: 162-164.

9. Westerman GH, Grandy TG, Ocanto RA, Erskine CG. Perceived sources of stress in the dental school environment. J Dent Educ,1993: 57: 225-231 
10. Heath JR MacFarlane TV, Umar MS. Perceived source of stress in dental students. Dent Update.1999; 26(3):9498

11. Sanders AE, Lushington K. Sources of stress for Australian dental students. J Dent Educ 1999; 63: 688697.

12. Morse Z, Dravo U. Stress levels of dental students at the Fiji school of medicine. Eur J Dent Educ 2007; 11:99-103.

13. Muirhead V, Locker D. Canadian dental students' perceptions of stress. J Can Dent Assoc 2007; 73:323.

14. Polychronopoulou A, Divaris K. A longitudinal study of Greek dental students' perceived sources of stress. $J$ Dent Educ 2010;74:524-30

15. Grandy TG, Westerman GH, Coms CE, et al. Perceptions of stress among third-year dental students. J Dent Educ 1989;53: 718-721

16. Rajab LD. Perceived sources of stress among dental students at the University of Jordan. J Dent Educ 2001: 65: 232-241.

17. Yap AU, Bhole S, Teo CS. A cross-cultural comparison of perceived sources of stress in the dental school environment. J Dent Educ1996: 60: 459-464.
18. Acharya S. Factors affecting stress among Indian dental students. J Dent Educ 2003: 67: 1140-1148

19. Bradley IF, Clark DC, Eisner JE, et al. The student survey ofproblems in the academic environment in Canadian dental faculties. J Dent Educ 1989: 53: 126131

20. Garbee WH, Jr, Zucker SB, Selby GR. Perceived sources of stress among dental students. $J$ Am Dent Assoc 1980: 100: 853-857.

21. Naidu RS, Adams JS, Simeon D, Persad S. Sources of stress anpsychological disturbance among dental students in the West Indies. J Dent Educ 2002: 66: 1021-1030.

22. Tisdelle DA, Hansen DJ, St Lawrence JS, Brown JC. Stress management training for dental students. $J$ Dent Educ 1984: 48: 196-202.

23. Schwartz RM, Eigenbrode CR, Cantor O. A comprehensive stressreduction program for dental students. J Dent Educ 1984: 48: 203-207.

24. Sugiura G, Shinada K, Kawaguchi Y. Psychological well-being and perceptions of stress amongst Japanese dental students. Eur J Dent Educ 2005: 9: 17-25

\section{How to cite this article:}

Mahalakshmi.M et al.2017, Perceived Source of Stress among Dental College Students in Kancheepuram District. Int J Recent Sci Res. 8(3), pp. 15937-15942. 